\title{
EXPERIMENTAL STUDY ON PATHOGENIC POTENTIAL OF SIX ACANTHAMOEBA STRAINS ISOLATED FROM FISH
}

\author{
Marie Veverková $^{1,2}$, Iva Dyková ${ }^{1,2}$ and Hana Pecková ${ }^{1}$
}

\author{
${ }^{1}$ Institute of Parasitology, Academy of Sciences of the Czech Republic, Branišovská 31, 37005 České Budějovice, Czech \\ Republic; \\ ${ }^{2}$ Faculty of Biological Sciences, University of South Bohemia, Branišovská 31, 37005 České Budějovice, Czech Republic
}

In the voluminous literature on pathogenic free-living amoebae, special attention has been paid to human pathogens, among others to strains of the genus Acanthamoeba Volkonsky, 1931. As a result of previous extensive studies on the occurrence of amphizoic amoebae in the organs of freshwater fishes (Dyková I., Lom J., Macháčková B., Sawyer T.K. 1996: Folia Parasitol. 43: 81-90; Dyková I., Macháčková B., Pecková H. 1997: Folia Parasitol. 44: 81-90; Dyková I., Lom J., Macháčková B. 1998a: Dis. Aquat. Org. 43: 205-210; Dyková I., Lom J., Macháčková B., Pecková H. 1998b: Folia Parasitol. 45: 17-26), 14 Acanthamoeba strains were isolated from organs of asymptomatic individuals (Dyková I., Lom J., Schroeder-Diedrich J.M., Booton G.C., Byers T.J. 1999: J. Parasitol. 85: 1106-1113).

The relationship revealed by molecular techniques between fish strains of the genus Acanthamoeba and strains that are commonly isolated from human infections, especially Acanthamoeba keratitis, strengthened the effort to clarify two important questions. First, what kind of reaction do the Acanthamoeba strains elicit in fish hosts and second, how fish in normal or debilitated condition cope with the permanent presence of amoebae in the environment.

Six of ten Acanthamoeba clones (3668/IV, 4422/II, 4436/III, 4337/II, 4800/V, 4465/I) characterised by Dyková et al. (1999, op. cit.) were selected for assessment of their pathogenicity. Since in preliminary experiments these clones induced only minor histopathological changes, immunosuppressive agents were applied in order to increase the susceptibility of fish to infection. Amoebae were cultured and harvested as previously described by Dyková et al. (1999, op. cit.). Immediately before application, the culture medium was washed off amoebae with phosphate buffered saline and cells were concentrated by centrifugation $(1000 \mathrm{rpm} / 10 \mathrm{~min})$.

Laboratory-bred common carp Cyprinus carpio L., tilapia Oreochromis niloticus niloticus (L.) and goldfish Carassius auratus auratus (L.) (5-8 cm in size) were used in the study. In addition, hybrids of isogenic homozygous line (HIHL) of common carp obtained from the Veterinary School, Hannover were used. Prior to the experiments, samples of brain, kidney, spleen and liver tissue of thirty control fish (ten of each species) were tested for the occurrence of amoebae by isolation attempts and histological examination. In total, 253 experimental fish were screened. To test the pathogenicity of Acanthamoeba strains on homoiothermic organisms we used three-month-old laboratory-bred NMRI mice. Assessment of pathogenicity was based on the presence of amoeba trophozoites and cysts in organs and on histopathological changes induced in experimental animals.
The design of individual experiments along with immunosuppressive agents used is given in Table 1. Experimental fish were held in groups of five in covered 5-litre tanks. Fish were starved for one day prior to challenge. The infectious dose (suspension of amoebae dissolved in $0.5 \mathrm{ml}$ of sterile phosphate buffered saline [PBS]) was administered perorally (p.o.) by syringe with cannula.

Prednisolone acetate (Sigma) in $0.5 \mathrm{ml}$ PBS was injected intraperitoneally (i.p.) as previously described by Steinhagen et. al. (Steinhagen D., Kruse P., Körting G.W. 1989: Dis. Aquat. Org. 7: 67-69) in three or nine doses of $42 \mu \mathrm{g} \cdot \mathrm{g}^{-1}$ body weight each, at $48 \mathrm{~h}$ intervals. Three doses of Hydrocortisone (Upjohn) $\left(140 \mu \mathrm{g} \cdot \mathrm{g}^{-1}\right.$ body weight each) in $0.5 \mathrm{ml}$ PBS were applied i.p. to carp at $24 \mathrm{~h}$ intervals according to Woo et al. (Woo P.T.K., Leatherland J.F., Lee M.S. 1987: J. Fish Dis. 10: 75-83). A solution of Triamcinolone acetonide (Sigma) $\left(200 \mu \mathrm{g} \cdot \mathrm{g}^{-1}\right.$ body weight) in $0.5 \mathrm{ml}$ PBS (Houghton G., Matthews R.A. 1986: Vet. Immunol. Immunopathol. 12: 413-419) was injected i.p. to six carp and eight goldfish. Furthermore, a group of six carp were administered $3 \mathrm{mg} /$ fish of Depo-Medrol (Upjohn) in $0.25 \mathrm{ml}$ sterile PBS intramuscularly (i.m.). In experiments in which immunosuppressive agents were used, the infectious dose of amoebae was administered $48 \mathrm{~h}$ after the last immunosuppressive injection.

To assess the rate of passage of amoebae through the digestive tract, infectious doses of four clones (3668/IV, 4436/III, 4337/II, 4465/I) were administered perorally to goldfish injected previously with nine doses of Prednisolone acetate (Sigma) $\left(9 \times 42 \mu \mathrm{g} \cdot \mathrm{g}^{-1}\right)$. Fish, in groups of five, were dissected at $24 \mathrm{~h}$, three and seven days post infection (p.i.) and amoebae remaining in the intestinal content were washed with $2 \mathrm{ml}$ of PBS, concentrated by centrifugation and counted using a haemocytometer.

To improve the detection of amoebae in tissues, indirect fluorescent antibody test (IFAT) with rabbit polyclonal antiserum specific to Acanthamoeba was performed. The immune serum was prepared according to Ausubel et al. (Ausubel F.M., Brent R., Kingston R.E., Moore D.D., Seidman J.G., Smoth J.A., Struhl K. [Eds.] 1999: Immunology. In: Short Protocols in Molecular Biology. Fourth Edition. John Wiley \& Sons, New York, pp. 11.1-11.30); the IFAT followed the procedure described by Kodet et al. (Kodet R., Nohýnková E., Tichý M., Soukup J., Visvesvara G.S. 1998: Pathol. Res. Pract. 194: 423-430).

Mice were administered three test clones $(3668 / \mathrm{IV}$, $4436 / \mathrm{III}, 4800 / \mathrm{V})$ at a concentration of $1.2-1.9 \times 10^{7}$ cells $\cdot \mathrm{ml}^{-1}$. A group of five mice were used for each clone and mode of 
Table 1. Design of experimental infections of common carps Cyprinus carpio L. (C), hybrids of isogenic homozygous line of common carp (HIHL), goldfish Carassius auratus auratus (L.) (G) and tilapias Oreochromis niloticus niloticus (L.) (T) with six Acanthamoeba clones.

\begin{tabular}{|c|c|c|c|c|c|}
\hline $\begin{array}{l}\text { Acanthamoeba } \\
\text { clone }\end{array}$ & $\begin{array}{l}\text { Exp. } \\
\text { No. }\end{array}$ & $\begin{array}{l}\text { No. fish / No. } \\
\text { positive fish }\end{array}$ & $\begin{array}{l}\text { Infectious dose per fish, } \\
\text { route of administration }\end{array}$ & $\begin{array}{l}\text { Time of } \\
\text { dissection }\end{array}$ & $\begin{array}{l}\text { Immunosuppressive doses, } \\
\text { route of administration }\end{array}$ \\
\hline \multirow{5}{*}{ 3668/IV } & 1 & 7T 6G 6C / 0 & $0.75 \times 10^{7}$ cells, p.o. & 20 days & 0 \\
\hline & 2 & $6 \mathrm{C} / 0$ & $0.75 \times 10^{7}$ cells, p.o. & 10 days & $\begin{array}{l}\text { Hydrocortisone, } \\
3 \times 140 \mu \mathrm{g} \cdot \mathrm{g}^{-1} \text {, i.p. }\end{array}$ \\
\hline & 3 & $7 \mathrm{C} / 0$ & $1.65 \times 10^{7}$ cells, p.o. & 10 days & $\begin{array}{l}\text { Prednisolone acetate, } \\
3 \times 42 \mu \mathrm{g} \cdot \mathrm{g}^{-1} \text {, i.p. }\end{array}$ \\
\hline & 4 & $10 \mathrm{G} / 0$ & $1.75 \times 10^{7}$ cells p.o. & $\begin{array}{l}7 \text { and } \\
11 \text { days }\end{array}$ & $\begin{array}{l}\text { Prednisolone acetate, } \\
9 \times 42 \mu \mathrm{g} \cdot \mathrm{g}^{-1} \text {, i.p. }\end{array}$ \\
\hline & 5 & 15 HIHL / 0 & $0.55 \times 10^{6}$ cells, p.o. & 10 days & 0 \\
\hline \multirow{2}{*}{ 4422/II } & 6 & $6 \mathrm{G} / 3$ & $0.85 \times 10^{6}$ cells, p.o. & 45 days & 0 \\
\hline & 7 & $6 \mathrm{G} / 6$ & $1.1 \times 10^{6}$ cells, p.o. & 45 days & 0 \\
\hline \multirow{6}{*}{ 4436/III } & 8 & $3 \mathrm{~T} / 0$ & $0.75 \times 10^{6}$ cells, p.o. & 45 days & 0 \\
\hline & 9 & $5 \mathrm{G} / 0$ & $0.75 \times 10^{6}$ cells, p.o. & 80 days & 0 \\
\hline & 10 & $6 \mathrm{C} / 2$ & $0.75 \times 10^{6}$ cells, p.o. & 22 days & 0 \\
\hline & 11 & $8 \mathrm{~T} 12 \mathrm{G} 8 \mathrm{C} / 1 \mathrm{G}$ & $1.25 \times 10^{7}$ cells, p.o. & 20 days & 0 \\
\hline & 12 & $6 \mathrm{C} / 0$ & $1.25 \times 10^{7}$ cells, p.o. & 10 days & $\begin{array}{l}\text { Prednisolone acetate, } \\
3 \times 42 \mu \mathrm{g} \cdot \mathrm{g}^{-1} \text {, i.p. }\end{array}$ \\
\hline & 13 & $5 \mathrm{G} / 0$ & $1.6 \times 10^{7}$ cells, p.o. & 3 days & $\begin{array}{l}\text { Hydrocortisone, } \\
3 \times 140 \mu \mathrm{g} \cdot \mathrm{g}^{-1} \text {, i.p. }\end{array}$ \\
\hline \multirow{4}{*}{ 4337/II } & 14 & $3 \mathrm{C} / 3$ & $0.55 \times 10^{7}$ cells, i.p. & 12 days & 0 \\
\hline & 15 & $6 \mathrm{C} / 1$ & $0.55 \times 10^{7}$ cells, i.p. & 12 days & $\begin{array}{l}\text { Triamcinolone acetonide, } \\
200 \mu \mathrm{g} \cdot \mathrm{g}^{-1} \text {, i.p. }\end{array}$ \\
\hline & 16 & $5 \mathrm{C} / 2$ & $1.6 \times 10^{7}$ cells, p.o. & 10 days & $\begin{array}{l}\text { Prednisolone acetate, } \\
3 \times 42 \mu \mathrm{g} \cdot \mathrm{g}^{-1} \text {, i.p. }\end{array}$ \\
\hline & 17 & $15 \mathrm{HIHL} / 1$ & $0.6 \times 10^{6}$ cells, p.o. & 10 days & 0 \\
\hline \multirow{8}{*}{$4465 / \mathrm{I}$} & 18 & $6 \mathrm{C} / 2$ & $0.85 \times 10^{6}$ cells, p.o. & 40 days & 0 \\
\hline & 19 & $6 \mathrm{C} / 2$ & $0.7 \times 10^{6}$ cells, p.o. & 40 days & Depo-Medrol, 3 mg, i.m. \\
\hline & 20 & $6 \mathrm{G} / 1$ & $0.9 \times 10^{6}$ cells, p.o. & 45 days & 0 \\
\hline & 21 & $6 \mathrm{G} / 5$ & $2.8 \times 10^{6}$ cells, p.o. & 40 days & 0 \\
\hline & 22 & $5 \mathrm{~T} 12 \mathrm{G} 6 \mathrm{C} / 0$ & $1.25 \times 10^{7}$ cells, p.o. & 20 days & 0 \\
\hline & 23 & $8 \mathrm{G}, 6 \mathrm{C} / 0$ & $0.65 \times 10^{7}$ cells, p.o. & 10 days & $\begin{array}{l}\text { Hydrocortisone, } \\
2 \times 140 \mu \mathrm{g} \cdot \mathrm{g}^{-1}(\mathrm{G}), \\
3 \times 140 \mu \mathrm{g} \cdot \mathrm{g}^{-1}(\mathrm{C}) \text {, i.p. }\end{array}$ \\
\hline & 24 & $10 \mathrm{G} / 3$ & $1.8 \times 10^{7}$ cells, p.o. & $\begin{array}{l}24 \text { hrs } \\
11 \text { days }\end{array}$ & $\begin{array}{l}\text { Prednisolone acetate, } \\
9 \times 42 \mu \mathrm{g} \cdot \mathrm{g}^{-1} \text {, i.p. }\end{array}$ \\
\hline & 25 & 15 HIHL / 0 & $3.15 \times 10^{6}$ cells, p.o. & 10 days & 0 \\
\hline \multirow{3}{*}{$4800 / \mathrm{V}$} & 26 & $7 \mathrm{~T} 6 \mathrm{G} 6 \mathrm{C} / 0$ & $1 \times 10^{7}$ cells, p.o. & 20 days & 0 \\
\hline & 27 & $6 \mathrm{G} / 0$ & $0.5 \times 10^{7}$ cells, p.o. & 11 days & $\begin{array}{l}\text { Prednisolone acetate, } \\
3 \times 42 \mu \mathrm{g} \cdot \mathrm{g}^{-1} \text {, i.p. }\end{array}$ \\
\hline & 28 & $8 \mathrm{G} / 0$ & $0.8 \times 10^{7}$ cells, p.o. & 11 days & $\begin{array}{l}\text { Triamcinolone acetonide, } \\
200 \mu \mathrm{g} \cdot \mathrm{g}^{-1} \text {, i.p. }\end{array}$ \\
\hline
\end{tabular}

infection, i.e., intranasal by instillation of a drop of amoebae suspension and peroral by adding the infectious dose to sterile drinking water (mice were previously thirsted for an hour). After two weeks the mice were examined histologically.

The experimental procedures were authorised by the Committee for Animal Experimentation of the Institute of Parasitology AS CR.
Tissue samples from all 30 control fish were negative for amoebae. The passage rate of amoebae through the fish intestine was as follows. Amoebae were present in goldfish intestine after $24 \mathrm{~h}$ at a mean concentration of $1 \times 10^{6}$ cells . $\mathrm{ml}^{-1}$. Three days p.i. the number of amoebae decreased to mean $1 \times 10^{4}$ cells $\cdot \mathrm{ml}^{-1}$. Seven days p.i. only one amoebic cyst was found in the content of intestine. 
All experiments testing infection with clones 3668/IV and 4800/I in tilapia, goldfish and carp (Exp. 1 to 5 and 26 to 28) were negative. Amoebae of clone 4422/II were detected sporadically in kidney interstitial tissue of goldfish. In nine goldfish, amoebae were found in adipose tissue in the abdominal cavity. Furthermore, granulomas containing amoebae were found in the spleen of one goldfish (Exp. 6 and 7).

The initial experiment (Exp. 10) with clone 4436/III revealed trophozoites and cysts in granulomas in the abdominal cavity of carp. A later experiment (Exp. 11) revealed amoebic trophozoites and cysts in the serous membrane of kidney and perirenal adipose tissue in only one goldfish. All tissues of fish treated with immunosuppressants and infected with clone 4436/III (Exp. 12 and 13) were negative. However, enlarged melanomacrophage centres were observed in spleen of Hydrocortisone-treated fish (Exp. 13).

Trophozoites and cysts of clone 4337/II were observed in tissues of all fish species infected intraperitoneally. In fish without previous immunosuppressive treatment, individual cysts were found in perirenal adipose tissue, hepatic serosa, and in islets of pancreatic tissue in the liver and spleen. In only one case IFAT revealed phagocytosed debris of trophozoites in splenic macrophages. After immunosuppressive challenge, amoebae were found in the capsula of the spleen and in perirenal adipose tissue in carp. In addition, cysts were discovered in interstitial tissue of the kidney and IFAT also revealed amoebae in melanomacrophage centres in the kidney. In one case only (Exp. 15), amoebae were identified in the brain tissue of carp.

Amoebae were detected in peritoneal adipose tissue in two fish treated with Prednisolone acetate (Exp. 16). In these specimens, IFAT revealed the presence of amoebic debris in the cytoplasm of macrophages. In all fish from this experiment, enlarged splenic melanomacrophage centres were observed. In one HIHL carp, amoebae were detected in adipose tissue surrounding the gonads (Exp. 17). Melanomacrophages in the spleen of these fish contained phagocytosed debris of amoebic cells.

Amoebae of clone 4465/I were found in small granulomas in adipose tissue among organs in peritoneal cavity (Exp. 20) and in the bile duct and spleen of goldfish (Exp. 21). The spleen of carp treated with Depo-Medrol contained IFATpositive macrophages 40 days p.i. (Exp. 19). Amoebae were isolated from the brain tissue in one goldfish following Prednisolone treatment and detected in the hepatic parenchyma and peritoneal adipose tissue $24 \mathrm{~h}$ p.i. (Exp. 24). In addition, in the same experiment, small amount of disseminated cysts occurred in intestinal serosa, serosa of liver and spleen and splenic melanomacrophage centres of goldfish.

Histological examination of and isolation attempts from experimental mice yielded no evidence of amoebic infection.

There are no reports about immunosuppression in fish in relation to amoebic infections. In our experiments we used the immunosuppressive agents tested in experiments with blood flagellates (Woo et al. 1987, op. cit.; Steinhagen et al. 1989, op. cit.). In order to raise probability of positive results of experimental infections, hybrids of isogenic homozygous line of common carp, more susceptible to flagellate infection with Trypanoplasma borreli (Wiegertjes G.F., Groeneveld A., van Muiswinkel W.B. 1995: Vet. Immunol. Immunopathol. 47: 153-161; Bunnajirakul S., Steinhagen D., Hetzel U., Körting W., Drommer W. 2000: Dis. Aquat. Org. 39: 221-229), were used.

The fact that infections with Acanthamoeba strains provoked in fish weakly pronounced histopathological changes could be due to various factors. (1) The most likely reason is that the strains used had lost their pathogenicity during longterm cultivation. This was reported for Acanthamoeba and Naegleria strains with high pathogenicity for humans. According to Stevens and O'dell (Stevens A.R., O'dell W.D. 1974: J. Parasitol. 60: 884-885), pathogenicity of a strain can be maintained by passaging the strain through mice. That, however, involves a high risk of contamination. Aseptically sampled tissues, primary isolates and culture passages are, as a rule, contaminated with bacteria that naturally occur in the host organism. Attempts of axenization of the culture through passaging, could, again, decrease the pathogenicity. (2) Another reason for low response in infected fish could be that the primary isolates were obtained from healthy fish. Nevertheless, Dyková et al. (1997, op. cit.) also isolated an amoeba strain of Hartmannella vermiformis from clinically healthy fish and this strain was able to produce infection in two fish hosts. (3) The conditions in which wild fish live are difficult to simulate in aquaria. Although the infectious doses of amoebae were higher than in other studies (Taylor P.W. 1977: J. Parasitol. 63: 232-237; Franke E.D., Mackiewicz J.C. 1982: J. Parasitol. 68: 164-166) they may not have been sufficient to cause pathologic condition in fish. Fish are naturally in permanent contact with a huge volume of water containing large numbers of amoebae. For example, according to Anderson (Anderson O.R. 1997: J. Euk. Microbiol. 44: 393398 ), the abundance of free-living amoebae in a pond can be as high as $1.8 \times 10^{6}$ cells per litre of water.

The administration of infectious doses was mostly peroral, since it was considered the natural route of infection. However, the actual portal of entry of infection is not known as yet. The fact that amoebae were not found in the wall of intestine within a short period p.i., was surprising. The intraperitoneal application of infectious doses resulted in more pronounced histopathological changes than the peroral administration.

The results of action of immunosuppressive agents used in this study differed from those reported by Woo et al. (1987, op. cit.) and Steinhagen et al. (1989, op. cit.) in infections with blood flagellates. In order to facilitate the assessment of the pathogenic potential of acanthamoebae, new ways of immunosuppression as well as adequate tests to evaluate immune status of experimental fish have to be implemented in future experiments.

This study was supported by the grant No. K 600514 from the Academy of Sciences of the Czech Republic. 